\title{
BILOBED LEAVES IN MOSSES? STRUCTURE AND ADAPTIVE SIGNIFICANCE OF PROXIMAL BRANCH LEAVES IN LEMBOPHYLLACEAE
}

\section{ДВУЛОПАСТНЫЕ ЛИСТЬЯ У МХОВ? СТРОЕНИЕ И АДАПТИВНОЕ ЗНАЧЕНИЕ ПРОКСИМАЛЬНЫХ ВЕТОЧНЫХ ЛИСТЬЕВ В LЕМВОРНYLLAСЕАЕ}

\author{
ULYANA N. SPIRINA ${ }^{1} \&$ MICHAEL S. IGNATOV ${ }^{2}$ \\ УЛЬЯНА Н. СПИРИНА ${ }^{1}$, МИХАИЛ С. ИГНАТОВ 2
}

Abstract

\begin{abstract}
Branch primordia in the moss family Lembophyllaceae demonstrate an outstanding polymorphism in proximal branch leaf arrangement around young branches. The first and second branch merophytes may not develop leaf lamina at all or form a deeply divided lamina or 'compound leaf', where 2-3(-4) individual laminae are somewhat distant one from another. Bilobed leaves occur in all genera of the family, being more common in the genera Weymouthia and Camptochaete. The lobate structure allows proximal leaves to form a slot-like clasps, likely having a protective significance. The early stages of branch development are shown in a series of sections of Weymouthia cochlearifolia.
\end{abstract}

Резюме

\begin{abstract}
Для зачатков веточек в семействе Lembophyllaceae характерен крайне высокий полиморфизм в расположении первых листьев веточек. Первые мерофиты, отделенные апикальной клеткой веточки, могут не развивать листовой пластинки или же давать глубоко разделенные на доли листья или даже образовывать “составные листья” из 2-3(-4) отдельных пластинок, расположенных на некотором расстоянии друг от друга. Двулопастные листья встречаются во всех родах семейства, будучи особенно характерными для родов Weymouthia и Camptochaete. Разделение на доли первых листьев веточки дает возможность образовывать “замковое соединение”, вероятно, имеющее функцию дополнительной защиты зачатка веточки. На сериях анатомических срезов показаны ранние стадии развития веточек Weymouthia cochlearifolia.
\end{abstract}

KEYWORDS: bryophytes, branch development, Lembophyllaceae, Weymouthia, axillary hairs

\section{INTRODUCTION}

In the gametophyte-dominated lineages of plants, the liverworts have leaves very variable in shape, which can be entire (e.g., in Jungermannia), bi-, tri- or quaidrilobed (e.g., in Scapaniaceae), with equal or unequal lobes, some of which can be highly specialized, like in Frullania, or even be strongly dissected as in Blepharostoma, Trichocolea, Telaranea, etc. (Schuster, 1966). Contrary to this, moss leaves are almost always simple and entire, with the only exception of Takakia, where they are divided into four linear lobes. In the present study we would like to point out that leaves of bilobed shape occur in some groups of mosses, although they are restricted to the early stages of branch development, and often referred as pseudoparaphyllia.

The term "pseudoparaphyllia" was introduced by Warnstorf (1906) for leaf-like structures around the branch primordium in Rhynchostegium (Brachytheciaceae). Curiously, later the family Brachytheciaceae was assumed as having no pseudoparaphyllia, while the cor- responding structures were interpreted as the proximal branch leaves, or scaly leaves (Ireland, 1971). Allen (1987) and Akiyama \& Nishimura (1993) also did not confirm the presence of pseudoparaphyllia in Meteoriaceae and Brachytheciaceae correspondingly. Ignatov (1999) found that in Brachytheciaceae and Meteoriaceae the arrangement of foliose structures around branch primordia, irrespective of their homology, delimit these families from other pleurocarpous families, correlating with molecular phylogenetic data (Huttunen \& Ignatov, 2004). This specific pattern has been explained by the fact that the first and second branch merophyte cells produce no lamina, cf. Scheme 1 (Spirina \& Ignatov, 2005). Subsequent studies demonstrated that the proximal branch leaf reduction occurs also in Leucodontaceae and Fontinalaceae (Ignatov \& Spirina, 2012).

A preliminary observation of the Lembophyllaceae revealed the Brachythecium-pattern in Camptochaete and also found that proximal leaves in it and other genera of this family are often dissected, or deeply subdivided into

1 - Biological Faculty, Tver State University, Zhelyabova 33, Tver 170100 Russia - Россия 170100 Тверь, Желябова, 33, Тверской государственный университет, Биологический факультет; e-mail: ulayspirina@mail.ru

2 - Tsitsin Main Botanical Garden of Russian Academy of Sciences, Botanicheskaya 4, Moscow 127276 Russia - Pоссия 127276 Москва, Ботаническая, 4, Главный ботанический сад PAH, e-mail: misha_ignatov@list.ru 

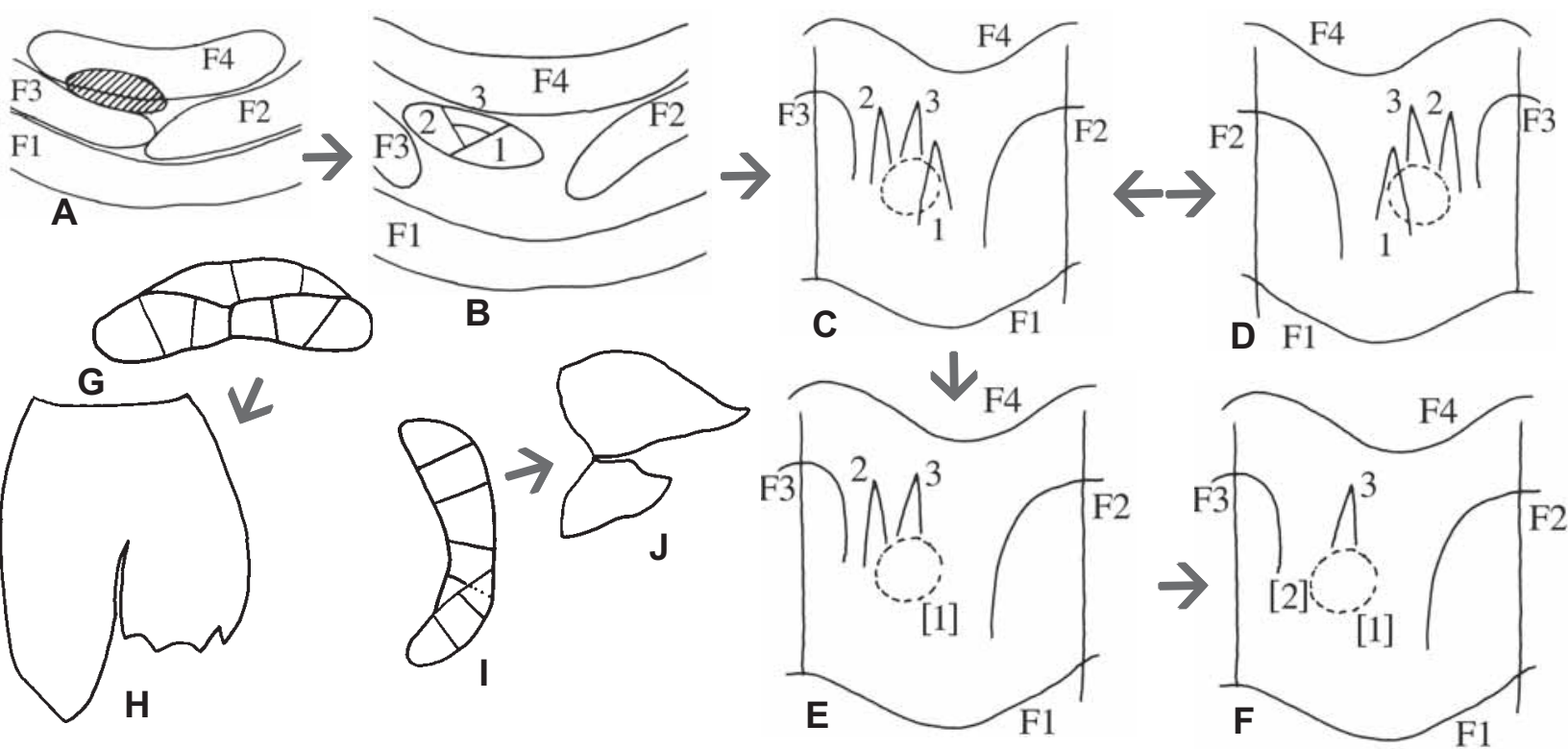

Scheme 1. A-B - C: early stages of branch development in pleurocarpous mosses, a schematic summary of Berthier (1971); C-D: arrangement of proximal branch leaves on stems with left and right spiral that may occur in the different branches of the same plant. $\mathrm{C}-\mathrm{E}-\mathrm{F}$ : series of first and second proximal branch leaf reduction. $\mathrm{G}-\mathrm{H}$ : bilobed leaf formation. I-J: compound leaf formation. F1-4 - order of stem leaves; 1-3 - order of branch leaves, numbers of reduced leaves are given in brackets.

lobes, and ultimately form a "compound leaf", where its parts, originated from one merophyte cell, appear as individual foliose structures at a certain distance one from another on the stem. Earlier the compound leaves were only briefly overviewed by Spirina \& Ignatov (2012) for Hypnum and Thamnobryum, but not described in detail, so this was the first aim of the present study. The rather frequent occurrence of bilobed proximal branch leaves in the family is another intriguing detail, which requires an explanation of their development and possible function.

The Lembophyllaceae originally included four genera: Camptochaete, Dolichomitra, Isothecium, and Lembophyllum (Brotherus, 1906). The subsequent challenges in the scope of the family were overviewed by Tangney (1997), who accepted in it Camptochaete, Fallaciella, Fifea, Lembophyllum and Weymouthia, moving ten genera to other families. Frey \& Stech (2009) returned to the family some of the excluded genera and added a few more genera, thus their number reached 14: Bestia, Camptochaete, Dolichomitra, Dolichomitriopsis, Fallaciella, Fifea, Isothecium, Lembophyllum, Looseria, Neobarbella, Pilotrichella, Rigodium, Tripterocladium, and Weymouthia. The genus Ortostichella has been tentatively accepted by these authors within Neckeraceae, as the molecular phylogenetic analysis put it, with $\mathrm{Po}$ rotrichum and Porothamnium, in a separate lineage (OPPclade) sister to Lembophyllaceae+Neckeraceae (Quandt et al., 2009; Huttunen et al., 2012).

\section{MATERIAL AND METHODS}

For SEM observation 20 species of eight genera from the Lembophyllaceae sensu Frey \& Stech (2009) were taken. We also added Nogopterium (=Pterogonium), which appeared in some molecular phylogenetic analyses within the Lembophyllaceae (Troitsky et al., 2008) or sister to that family (Huttunen et al., 2012). Three species of Orthostichella were included as previously referred to the Lembophyllaceae; and as the Neckeraceae were found in several analyses between Orthostichella and the rest of Lembophyllaceae, three genera from the Neckeraceae (Alleniella, Porotrichodendron and Thamnobryum) were also added to SEM study. At least ten stems of each species were studied for their upper 10-15 mm with 10-30 buds, which position allowed us to see them reasonably complete. Comparison of two specimens of Camptochaete leichardti, two of Weymouthia cochlearifoliai, and three of Pilotrichella flexilis from distant localities was also done. Supplementary observations under a light microscope were done for general observation only, as in most cases bud structure was not unequivocally understood due to proximal branch leaf overlapping.

For SEM observations, herbarium material was fixed in $4 \%$ glutaraldehyde for 5 days, post-fixed with $1 \%$ osmium tetroxide in Na-phosphate buffer, $\mathrm{pH}=6.8$, for 10 hours. Then material was dehydrated through a graded ethanol/acetone series to $100 \%$ acetone and dried at a critical point, covered by gold and observed under LEO-430.

For anatomy observations, material was also taken from a recently collected dried specimen of Weymouthia cochlearifolia. Apical parts of shoots were isolated, leaves were removed. Prepared stems were deaerated and fixed in $2.5 \%$ glutaraldehyde in $0.05 \mathrm{M}$ PBS for 3 hours, postfixed with $1 \%$ osmium tetroxide in PBS, $\mathrm{pH} 6.8$, for 6 hours. Then material was dehydrated through an ascending ethanol-acetone series to $100 \%$ acetone. After that 
samples were embedded in araldite 6005 medium, according to the protocol of manufacturer.

Sections were cut $2 \mu \mathrm{m}$ thick with glass knives, put on glass slides without mounting medium, stained by $0.01 \%$ berberin and photographed under Olympus FV1000 with $473 \mathrm{~nm}$ laser.

Material for LSCM was taken from dried herbarium specimens and prepared in two ways: 1) samples were fixed in $4 \%$ paraformaldehyde in $0.05 \mathrm{M}$ PBS pH 7.0 with $0.01 \%$ Triton-X, $0.01 \%$ Nonidet P- 40 and $0.01 \%$ FB28 for 3 hours, then stained by $0.1 \mathrm{mM}$ DAPI for $15 \mathrm{~min}$; 2) shoots without fixation were stained by $0.1 \mathrm{mM}$ DAPI or $0.01 \%$ berberin for $15 \mathrm{~min}$, then both types of samples were investigated under Olympus FV-1000 with $407 \mathrm{~nm}$ and $473 \mathrm{~nm}$ lasers.

\section{RESULTS}

I. Branch primordia diversity in the Lembophyllaceae and related lineages

The SEM pictures 1-69 illustrate branch primordia in the following order: first, in Figs. 1-30 are shown Isothecium, Bestia, Dolichomitriopsis, Rigodium and Pilotrichella, the genera found in the basal grade of the family (Quandt et al., 2009), but not the core of the family (Tangney, 1997). Then the representatives of "core Lembophyllaceae" follow, including Lembophyllum, Camptochaete and Weymouthia (Figs. 31-51) and after them Orthostichella (Fig. 52-60) and genera of the Neckeraceae, Alleniella, Thamnobryum and Porotrichodendron are shown (Fig. 61-69).

Genera of the Lembophyllaceae show an outstanding polymorphism of the proximal branch leaf structure and arrangement. The variation within some shoots of a single specimen was sometimes comparable with the differences between specimens of the same species and between species of the same genus.

Conclusions on leaf reduction or splitting into several parts are based on the Scheme 1, position of leaves and their parts, with the special attention of overlay in leaf corners and at leaf decurrencies. Compared with other groups of pleurocarps, the angle between the proximal branch leaves in the Lembophyllaceae is broader, sometimes nearly $180^{\circ}$ [thus without any overlaying corners], in these cases tracing of the leaf spiral was the main basis for our conclusions.

In Isothecium (Figs. 1-5, 75), most buds are characterized by the reduction of one or two outer proximal branch leaves, but sometimes they both are present. Some proximal branch leaves are strongly divided into lobes, for example \#4 in Fig. 3, \#4 in Fig. 4, and \#3 in Fig. 5. The latter interpretation is not evident at once, however it would be impossible to provide another numbering considering leaf sequence which is apparent from overlays. The first and second leaves, when developed, are usually compound, as well as the third and fourth leaves. The second and third leaves, when compound, are represented by maximal number of parts in comparison with other leaves of the same bud.
Bestia (Figs. 6-9) is very variable. The first leaf is often reduced or very small (Figs. 7, 9). The second and sometimes the third proximal branch leaves are clearly compound and also their interpretation is complicated due to "sub-opposite" leaf arrangement (cf. Fig. 7) caused by a wide angle between leaves. The leaf arrangement in Fig. 6 also is confusing, as it looks as if leaf \#4 is overlapping leaf \#3, which is impossible. However, this is only partial, one-lobe overlapping; similar examples are shown in Figs. 70-81. The fact that the right lobe of leaf $\# 3$, which is hardly seen, exists and overlaps leaf \#4 is evident from the presence of axillary hair (marked as "ah"), which cannot belong to any leaf except \#3 and can be visible behind \#4 only in the case if \#3 overlaps \#4. The similar overlap in sinus between lobes is seen in Fig. 7, and in Fig. 8 the further growth of leaf 2 with a linear "adventive lobe" also may comprise this type of clasps. An outstanding feature of Bestia is the abundance and early development of the axillary hairs.

The genus Dolichomitriopsis is characterized mostly by Brachythecium-type, Leucodon-variant of the proximal branch leaf pattern, with two first leaves reduced and the third one subdivided into two or more lobes (Figs. 10-12), although in few buds small lamina of the second leaf is developed (e.g. Fig. 13). The third leaf consists of two lobes which are often placed one upon another and frequently have an extended base covering nearly twothirds of branch primordium.

Rigodium (Figs. 14-21) is similar to the previous genus in constant reduction of the first leaf and occasional presence of the second one, although the latter has been observed more frequently than in Dolichomitriopsis. Another difference from the latter genus is that when the second leaf is developed it is always compound, consisting of 3-5 triangle segments often without apparent connection to each other at the level of stem surface. The third leaf is hood-like, its shape varies from entire to bilobed and dissected almost to the base and sometimes it can be compound.

In Pilotrichella species basic type of branch primordia (Figs. 24-26), Brachythecium-type (Fig. 30) and intermediate variant with the first leaf reduced and the second one developed are present (Figs. 22-23, 27-29). Pilotrichella ampullacea and P. cuspidata have all three proximal branch leaves well-developed and entire. P. rigi$d a$ has primordia with entire hood-like proximal leaves in different stages of reduction, comprising a transition from buds with all three leaves developed (not shown) to buds with the third proximal leaf in the outermost position (Fig. 23). In P. pentasticha the first leaf is reduced in most cases, but once it was found; the second leaf is always present and can be either entire or slightly dissected. P. flexilis has a reduction of first leaf in most cases, but sometimes of both first and second one; the third leaf is entire or bilobed. If primordial leaves are dissected into lobes or laciniate, they clasp over the bud (cf. Figs. 70-72, 74). 

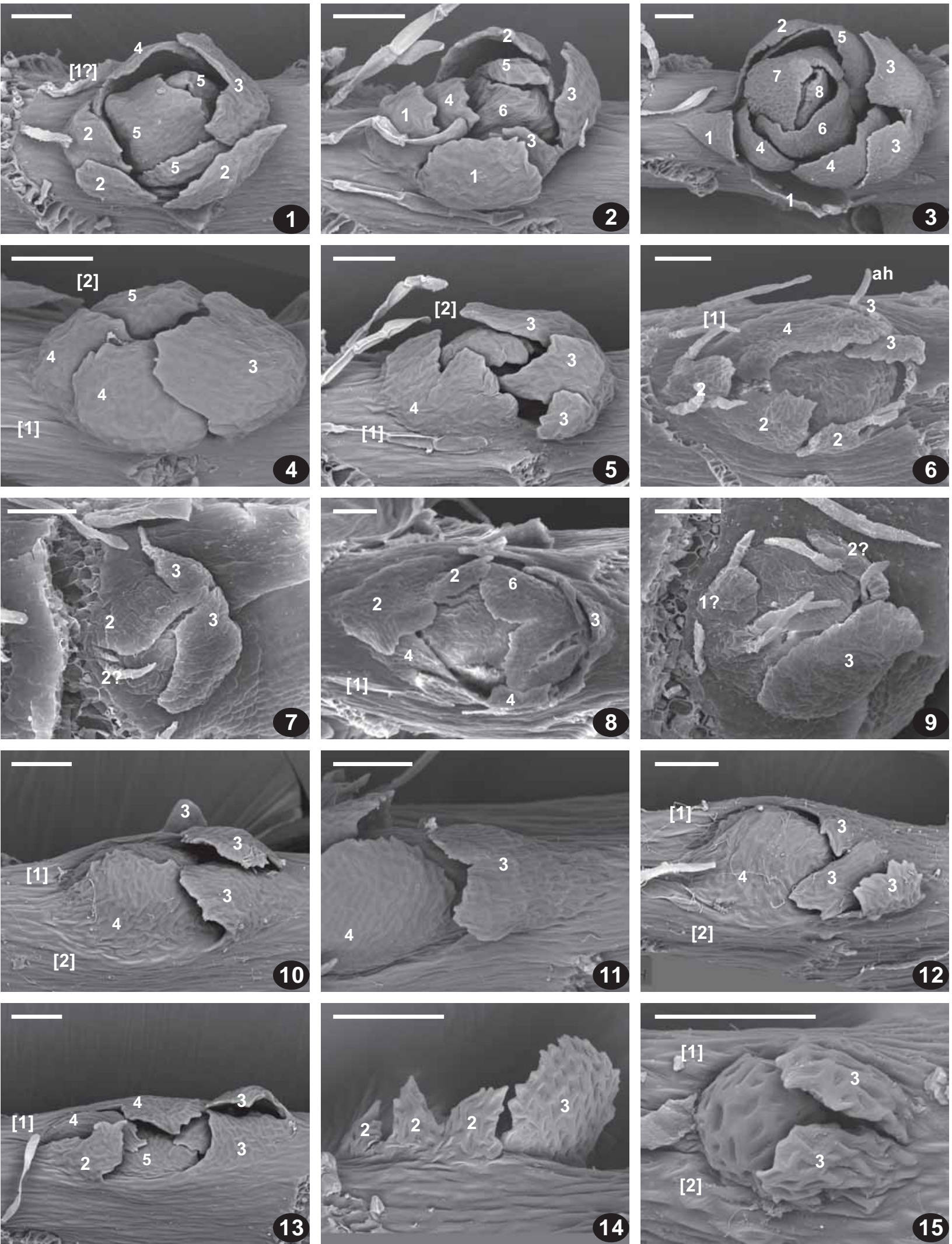

Figs. 1-15. Branch primordia of Lembophyllaceae taxa (SEM): 1-5: Isothecium alopecuroides (Lam. ex Dubois) Isov. (Russia, Ignatov \& Ignatova, 56/2); 6-9: Bestia longipes (Sull. \& Lesq.) Boulay ex Broth. (USA, Shevock 29927); 10-13: Dolichomitriopsis crenulata S. Okamura (Japan, 19 Nov. 1961, Ikegami); 14-15: Rigodium toxarion (Schwägr.) A. Jaeger (Costa-Rica, Crosby 10871). Scale bar: $50 \mu \mathrm{m}$ for all. Numerals indicate the leaf nubmer according to Scheme 1, with numbers of reduced leaves given in brackets and parts of compound leaves marked by the same numeral. 

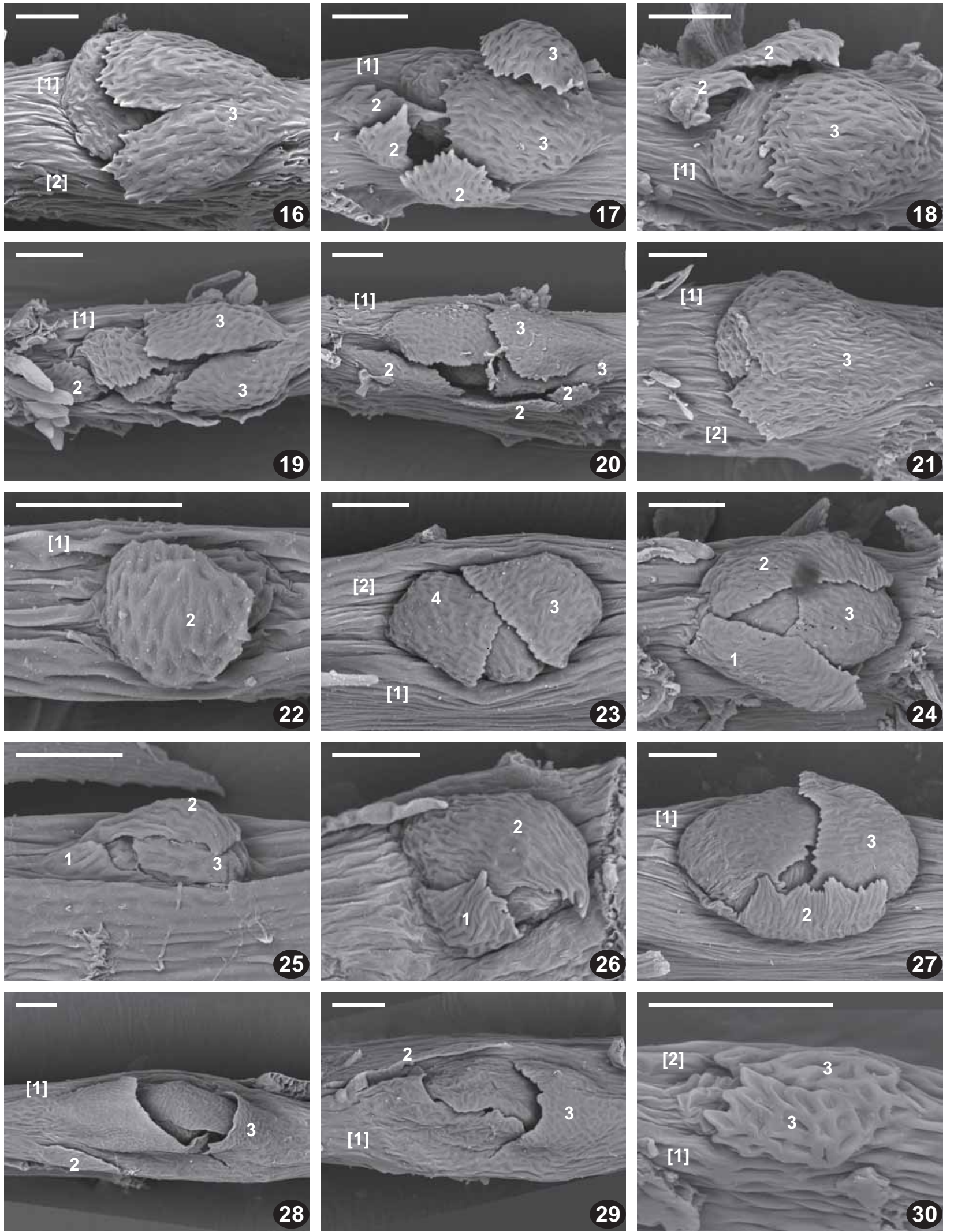

Figs. 16-30. Branch primordia of Lembophyllaceae taxa (SEM): 16-18: Rigodium brachypodium (Müll. Hal.) Paris (Chile, Crosby 11893); 19-21: Rigodium implexum Kunze ex Schwägr. (Chile, Crosby 12170); 22-23: Pilotrichella rigida (Müll. Hal.) Besch (Costa Rica, Leisner 1447); 24: Pilotrichella ampullaceae (Müll. Hal.) A. Jaeger (Tanzania, Pócs et al., 87165/AF); 25: Pilotrichella cuspidata Broth. (Tanzania, Pócs 87039/B); 26-27: Pilotrichella pentasticha (Brid.) Wijk \& Margad. (Nicaragua, Stevens 16137); 28-30: Pilotrichella flexilis (Hedw.) Ångström (Honduras, Allen 12016). Scale bar: 50 mm for all. Numerals indicate the leaf nubmer according to Scheme 1, with numbers of reduced leaves given in brackets. 

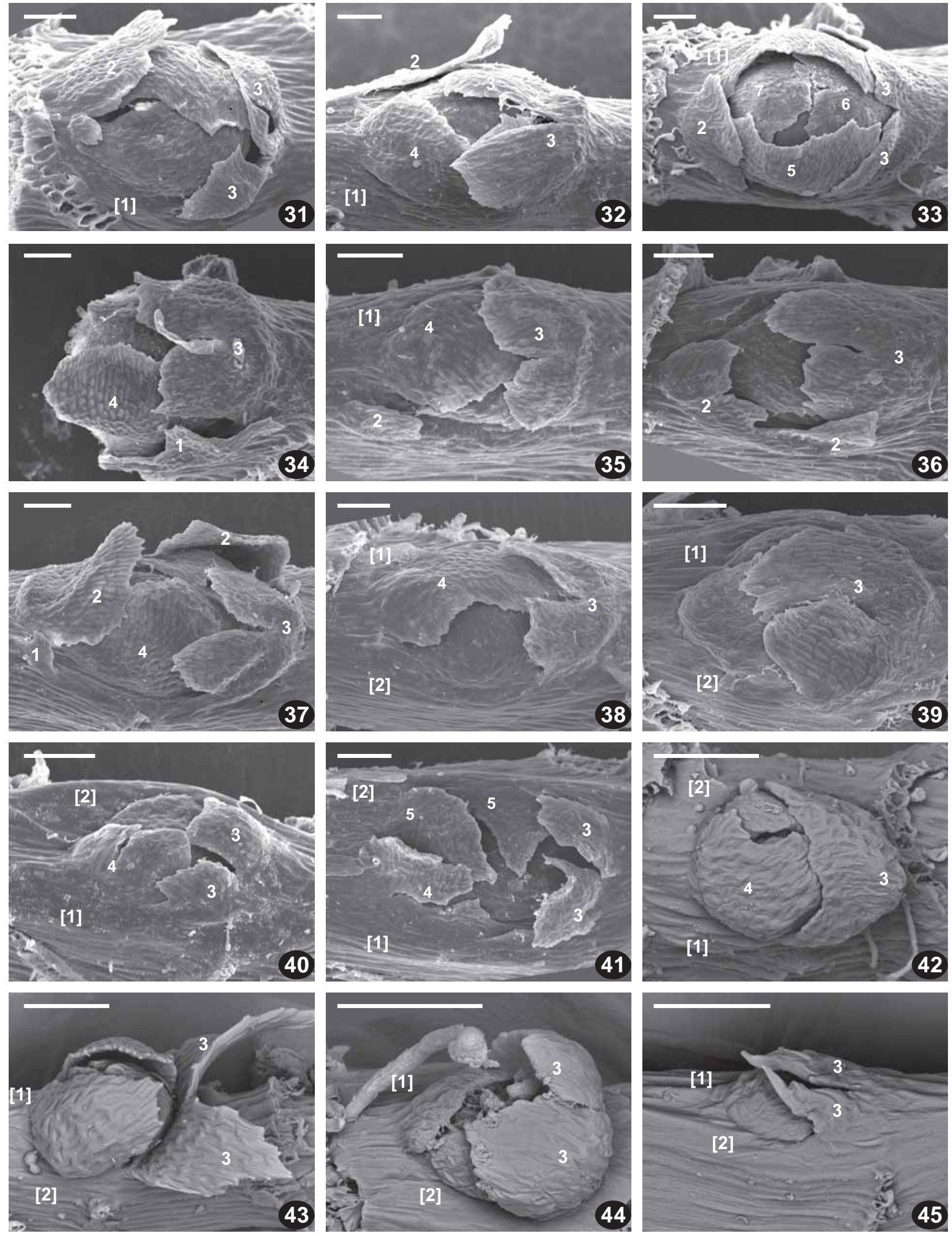

Figs. 31-45. Branch primordia of Lembophyllaceae taxa (SEM): 31-33: Lembophyllum divulsum (Hook. f. \& Wilson) Lindb. (Australia, Streimann 59035); 34-39: Camptochaete arbuscula (Sm.) Reichardt (Australia, Streimann 49126); 40-41: Camptochaete excavata (Taylor) A. Jaeger (Australia, Streimann 65228); 42-44: Camptochaete angustata (Mitt.) Reichardt (New Zealand, Fife \&Tan, 94-274); 45: Camptochaete leichardtii (Hampe) Broth. (Australia, Streimann 38424). Scale bar: 50 mm for all. Numerals indicate the leaf nubmer according to Scheme 1, with numbers of reduced leaves given in brackets and parts of compound leaves marked by the same numeral. 

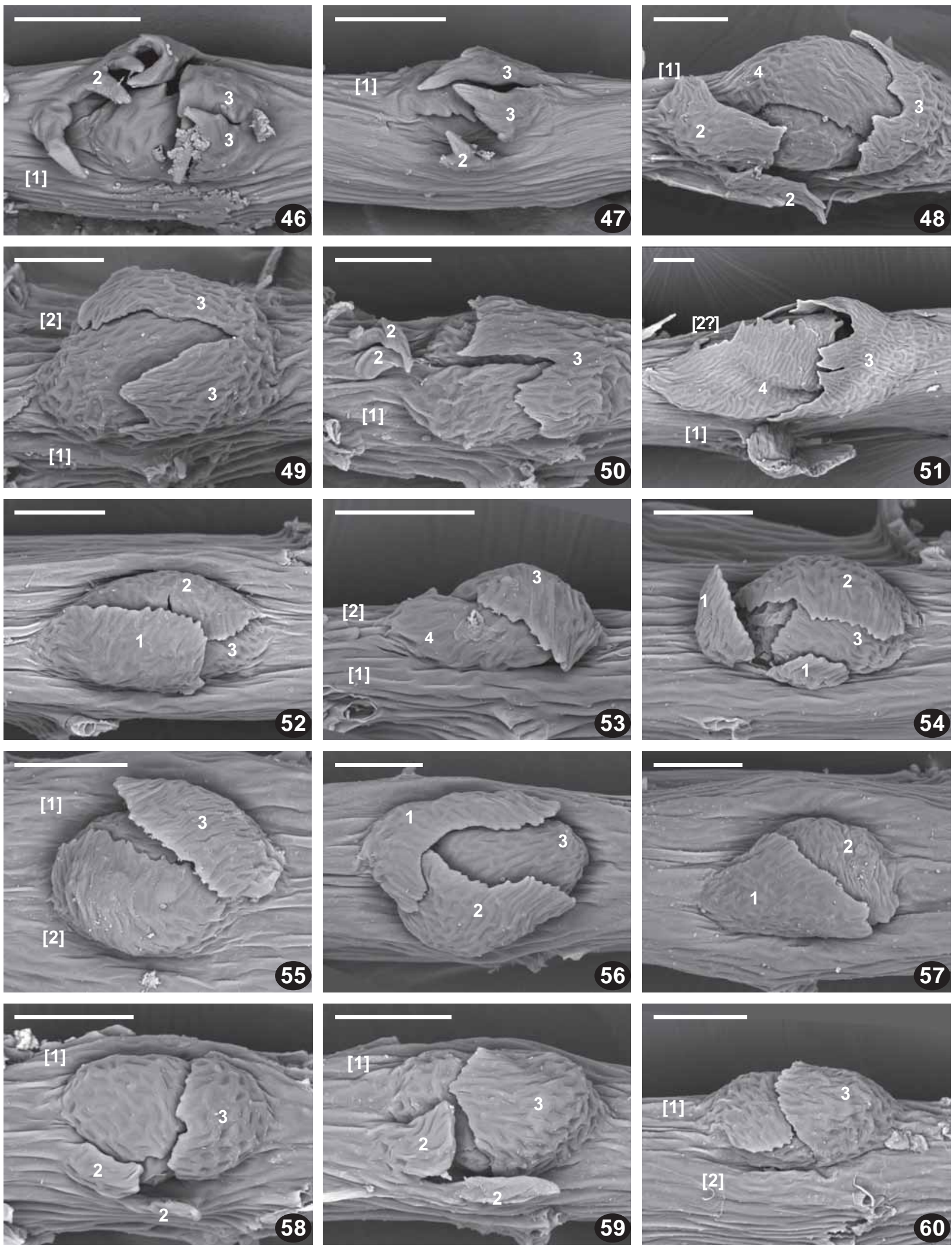

Figs. 46-60. Branch primordia of Lembophyllaceae and OPP-clade taxa (SEM): 46-47: Camptochaete leichardtii (Australia, Streimann 38424); 48-50: Weymouthia mollis (Hedw.) Broth. (Australia, Streimann 59031); 51: Weymouthia cochlearifolia (Schwägr.) Dixon (New Zealand, 17.X.2013 Spirina); 52-55: Orthostichella hexasticha (Schwägr.) W.R. Buck (Cuba, Pócs et al. 9183/A); 56-57: Orthostichella rigida (Müll. Hal.) B.H. Allen \& Magill (Madagascar, Dorr \& Barnett 3197); 58-60: Orthostichella versicolor (Müll. Hal.) B.H. Allen \& W.R. Buck (Madagascar, Dorr et al. 3468). Scale bar: $50 \mathrm{~mm}$ for all. Numerals indicate the leaf nubmer according to Scheme 1, with numbers of reduced leaves given in brackets and parts of compound leaves marked by the same numeral. 

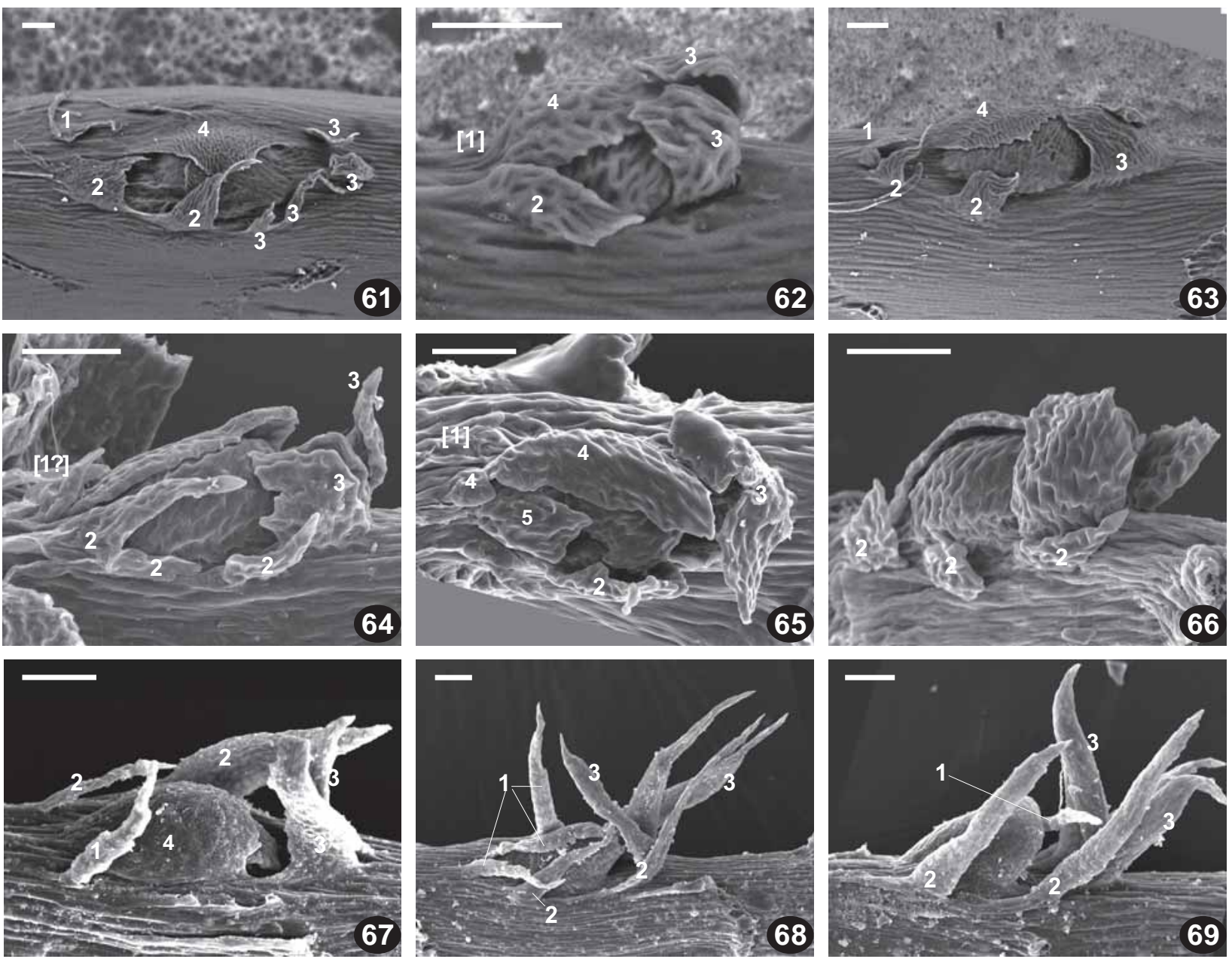

Figs. 61-69. Branch primordia of Neckeraceae taxa (SEM): 61-63: Porotrichodendron superbum (Taylor) Broth. (Ecuador, Øllgaard et al., 9.VII.1980); 64-66: Thamnobryum alopecurum (Hedw.) Nieuwl. ex Gangulee (Russia, Ignatov \& Ignatova, 13.IX.2005); 6769: Alleniella complanata (Hedw.) S. Olsson, Enroth \& D. Quandt (Russia, Ignatov \& Ignatova, 316/2). Scale bar: $50 \mu \mathrm{m}$ for all.

In Lembophyllum the first leaf is steadily reduced but the second one is developed, it is entire or slightly dissected, while the third one is divided into 2 or 3 lobes almost to the base (Figs. 31-33).

Camptochaete pattern is almost always of Brachythecium-type, with the first and second leaves reduced (Figs. $34-36,38-47$ ), although occasionally the second leaf is developed (in each species of the genus studied) and once all proximal leaves were seen around branch primordium (Fig. 37), although the first one had only a very small lamina. If the second leaf is present it is either dissected into 2-4 lobes or entire. The third leaf often is bilobed and in a number of cases has clasps (Figs. 35, 40), similar to those shown in Figs. 70-72, 78, 81 for Pilotrichella flexilis and Weymouthia cochlearifolia. In rare cases the third leaf is entire (Fig. 42).

Buds of Weymouthia (Figs. 48-51) always have a reduced first leaf. The second one is either present or reduced, but if developed it is deeply dissected or compound. The third leaf is well developed, hood-like and bilobed with additional shallow dissections of main two parts into smaller ones.
Summing up, most genera of the Lembophyllaceae are characterized by various level of reduction of proximal branch leaves within the species and sometimes even within the single shoot. There are buds with the basic type of branch primordia, i.e. the first leaf is in the 4 o'clock position, otherwise the outermost developed leaf is the second one, near 11 o'clock position, or the third one, and then pointing downwards, thus representing Brachythecium-type. In many cases proximal branch leaves are divided, dissected or representing a compound leaf, although like in the case of reduction, different species from one genus may have different degree of leaf splitting. Generally, the variation is slightly higher in species from the basal part of a phylogenetic tree: the first proximal branch leaf occasionally occurs here, while in the core Lembophyllaceae it is very rare, although exceptions exist. Bilobed leaves are observed in all genera of the family, although they are developed not in all the buds.

In Orthostichella, all types of primordia were found. Orthostichella rigida has the basic type of primordia (Figs. 56-57), with well-developed and entire first and 

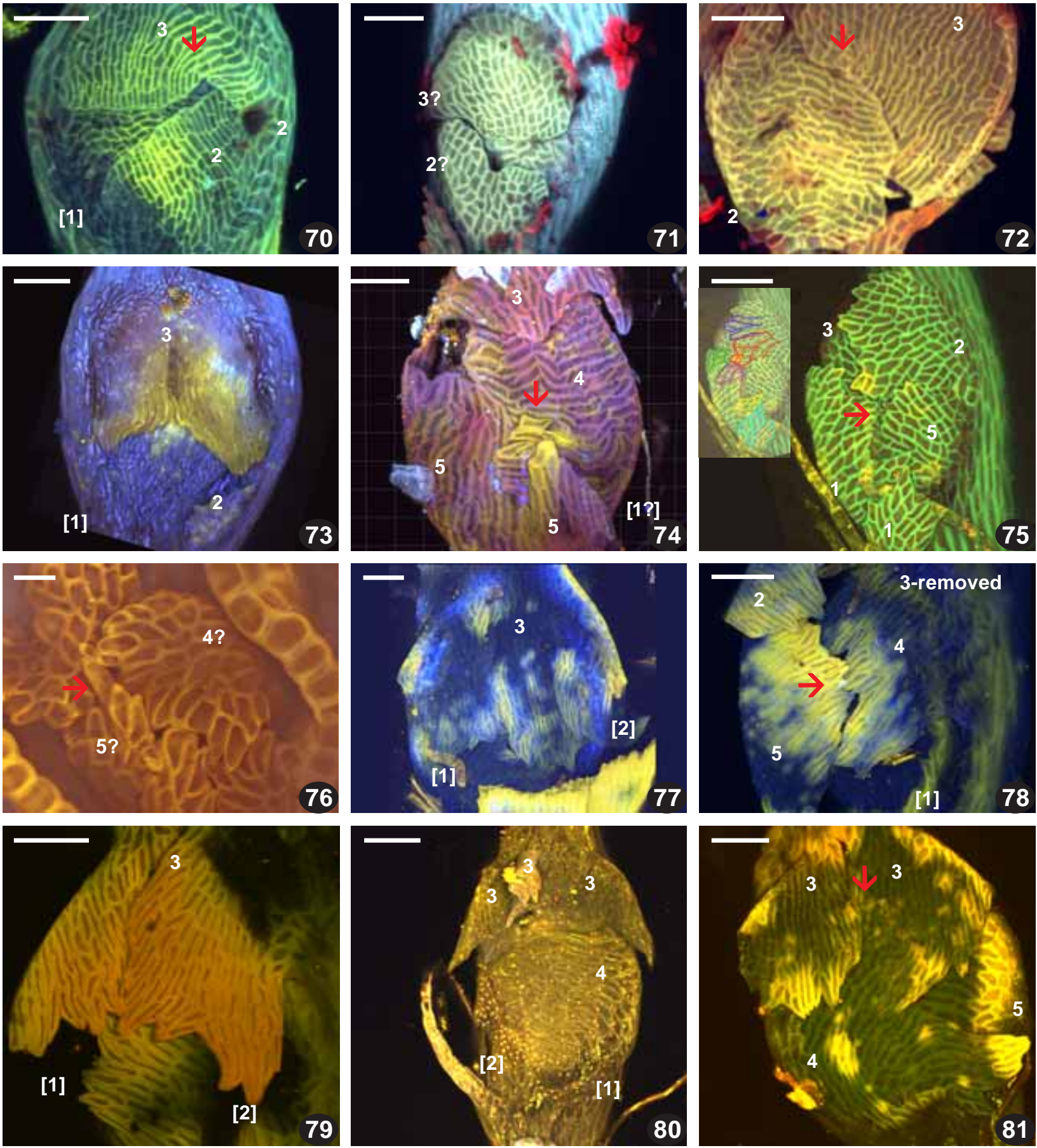

Figs. 70-81. Branch primordia of Lembophyllaceae (LSCM): 70-74: Pilotrichella flexilis (Honduras, Allen 12016).; 75: Isothecium hakkodense Besch. (Russia, Bakalin K-16-45-07); 76: Nogopterium gracile (Hedw.) Crosby \& W.R. Buck (Canary Is., April 2014 Spirina); 77-81: Weymouthia cochlearifolia (New Zealand, 17.X.2013 Spirina); Scale bar: $50 \mu \mathrm{m}$ for all. Numerals indicate the leaf nubmer according to Scheme 1, with numbers of reduced leaves given in brackets and parts of compound leaves marked by the same numeral. Arrows point clasps forming by lobed or laciniate leaves. Fig. 75 includes scheme of cell blocks appeared from some marginal cells functioned in an apical leaf cell mode.

second proximal branch leaves; buds of $O$. hexasticha vary from basic type with entire leaves (Fig. 52) to basic with first leaf compound (Fig. 54) and to Brachythecium-type (Figs. 53, 55); O. versicolor has reduced first leaf, while the second one is either absent (Fig. 60) or compound (Figs. 58-59).
Nogopterium has strongly and variously dissected leaves, with some bilobed, and the clasping pattern over primordium is observed in many buds (Fig. 76).

In three sampled genera of the Neckeraceae the tendency to compound leaves development is conspicuous. In Porotrichodendron the size of primordium seem- 
ingly determines the degree of splitting: in narrower and younger stems, and therefore with smaller buds (Fig. 62), proximal branch leaves are less divided (cf. also Figs. 61 and 63). Larger branch primordia look more flattened (Figs. 61), indicating somewhat immersed position of the apical cell, which is the common case in the Neckeraceae, as well as in Lembophyllaceae.

Branch primordia in Thamnobryum are surrounded by small foliose structures, some of them being clearly connected by shallow ridge between separated parts (Figs. 64-65). However in other cases (Fig. 66) common origin of these structures from one merophyte is not apparent at once. In such cases, their identity is deduced mostly from the comparison of their positions with those in other buds. Ignatov \& Spirina (2012) supported this conclusion also by the anatomy study.

Alleniella provides further specialization of the first branch primordial leaves, which are more distant from the bud and have a strikingly different linear shape. However their arrangement similar to that in Thamnobryum, tendency to be entire in smaller primordia (Fig. 67), and connections by decurrent bases (Fig. 68, leaf 2) leave no doubt on their homology. Most proximal leaves are regularly compound in Alleniella and abruptly different from the fourth and subsequent leaves.

\section{Anatomy of Weymouthia cohlearifolia: stem api- cal part and branch primordia}

The genus Weymouthia was selected as it belongs to the core Lembophyllaceae (Tangney, 1997; Goffinet et al., 2009; Frey \& Stech, 2009; Quandt et al., 2009) and often has bilobed proximal branch leaves (Figs. 48-51, $77-81$ ) in 12 o'clock position, divided to $1 / 2$ or $3 / 4$. They are usually 22-36 cells wide at base (having equal number of cells below each lobe), and 10-13(-16) cells long, being composed proximally by short cells, with length to width ratio 2:1, and in lobed by elongate cells, 3-5(-8):1.

Apical cell is $40-45 \mu \mathrm{m}$ long and $20-25 \mu \mathrm{m}$ wide, broadly ovoid, but somewhat asymmetric (Figs. 82-83). The most recently originated merophytes form cell wall at narrower angle with the free surface of apical cell in comparison with illustrations of other pleurocarpous mosses (e.g. Berthier, 1971; Spirina \& Ignatov, 2005). Their divisions cut off cells at a broad arc, ca. $180^{\circ}$, as seen from above (Fig. 84).

Stem leaves form clearly double-layered base being only 5 cells in height (Fig. 82), being at the same time 12-15th from the apex, as the first merophytes remain small and forming flat or only slightly convex area near the stem apical cell. Axillary hair mother cells can be recognized by their shape and position in leaf axils at 40 $\mu \mathrm{m}$ from stem apex (Fig. 83), and at ca. $50 \mu \mathrm{m}$ from stem apex they approach already to their characteristic shape (Fig. 85). Originally they occur by two per axil, being less than $4 \mu \mathrm{m}$ in diameter, sitting ca. $13 \mu \mathrm{m}$ one from another, at the distance determined by large rectangular cells, each underlaid by two cells.
Branch initials at 40-50 $\mu \mathrm{m}$ from the stem apex have two differentiated merophytes, consisting of four and two cells respectively (Figs. 85). As it can be concluded from longitudinal sections (Figs. 87-89) and SEM images (Figs. 48-51), Weymouthia develops no foliose structures homologous to the first branch leaf. The second leaf is also usually absent, although in some buds compound leaves with small laminae are observed (Fig. 50).

First divisions of the branch apical cell are shown in a series of sections somewhat subtransverse to the axis of branch initial apical cell (four sections out of ten, a-j, are shown in Fig. 91). The apical cell itself is broader than long $(50 \times 20 \mu \mathrm{m})$, probably being strongly pressed by distally and proximally situated leaves. The first branch merophyte cell is cut off from the branch apical cell in the 4 o'clock position (cf. Figs. 91a-dh). The second merophyte cut off at ca. $120^{\circ}$ from it, appearing in the 8 o'clock position. Its appearance is unusual as it is composed of a series of cells fairly irregular in shape, some being quite rounded. A similarly "too rounded" cells are observed in other sections of Weymouthia (e.g. in 93r-v), near the bottom of the apical cell.

Another peculiar feature of the branch apical cell of Weymouthia is that being at first somewhat raised above the stem surface (Figs. 82, 85) it undergoes a sinking into the stem tissue. At $250 \mu \mathrm{m}$ from the stem apex it occurs in a shallow hollow (Figs. 82, right below, 88), while further down along the stem, ca. $400 \mu \mathrm{m}$ from apex, it appears at the hollow bottom at $15 \mu \mathrm{m}$ below the stem surface level (Fig. 89). A similar immersion is observed in Isothecium alopecuroides (Fig. 90).

A series of transverse sections is shown in Fig. 92, being almost complete, represented by 11 of 12 sections. Whole height of the apical cell is $22 \mu \mathrm{m}$, which is somewhat longer than in Fig. 89 and shorter than in Fig. 88, being thus well within the variation of this character in Weymouthia. Differentiation of merophytes represents a standard pattern: the 4-8-12o'clock positions, at almost exact $120^{\circ}$ angle. At the stem surface the apical cell and few tightly adjoining merophytes are somewhat separated from the surrounding leaves \#4 and 5, thus the stage can be assumed as about the same or a little later than those in Figs. 88-89.

The first and second branch merophyte descendants are comprised as more or less regularly arranged cells outside the next leaves \#4 and \#5 near stem surface (Figs. $92 \mathrm{c}, \mathrm{d})$, while below they are multistratose. Such interpretation is based on the Scheme 1, as well as on Figs. 87-88. Thus, the outermost "obvious" leaf is the third one: it is situated in 120 'clock position.

This third leaf is subdivided into lobes at about a stem surface level (Fig. 92c) and below this level the place of separation is clearly seen by shorter anticlinal cell wall, which is also more conspicuous due to a brighter cellulose fluorescence (arrowed on Fig. 92f, and cf. also 92d 

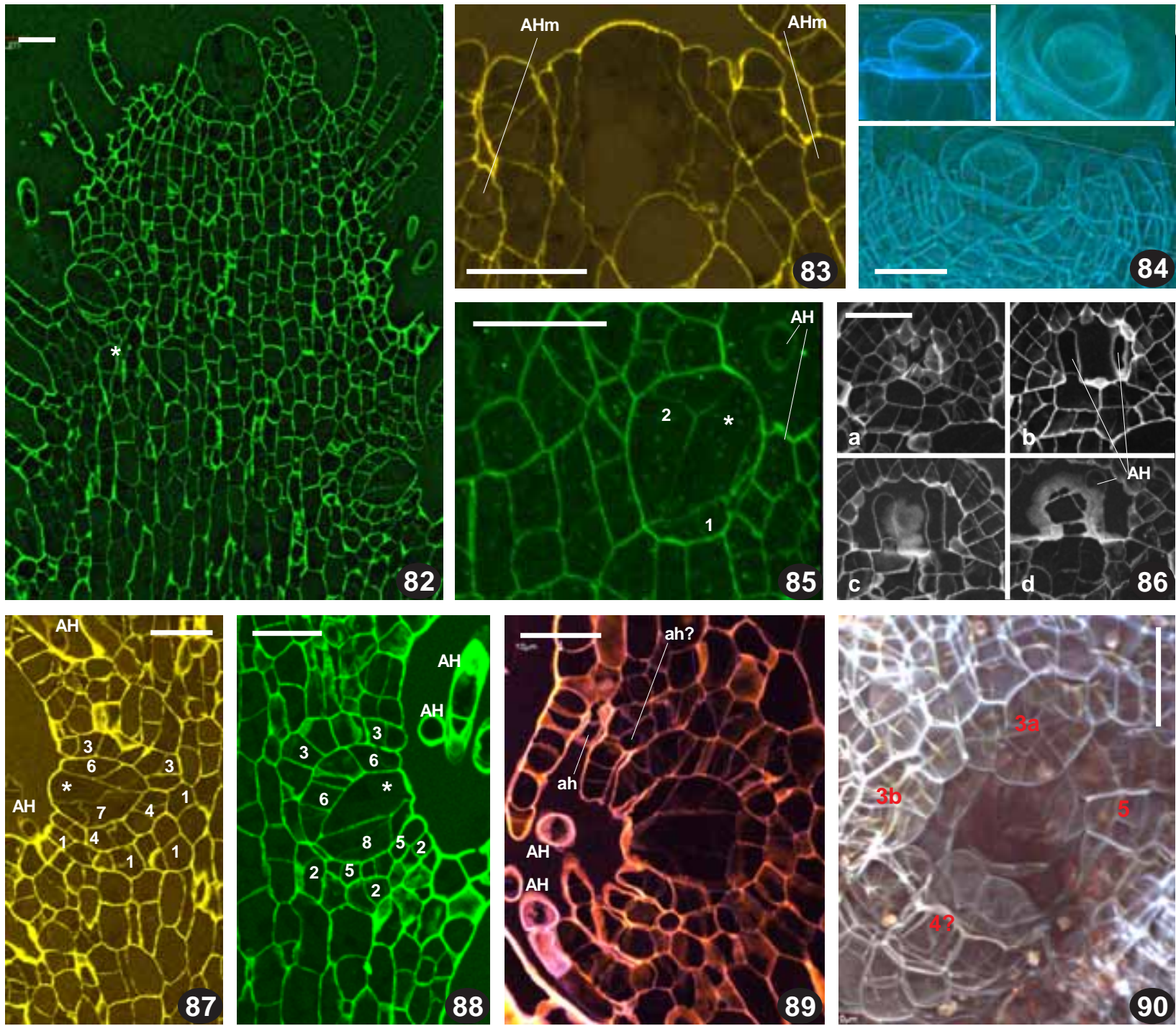

Figs. 82-90. Apical region and branch primordia at different stages of development of Weymouthia cochlearifolia (72-89) and Isothecium alopecuroides. Scale bar: $20 \mu \mathrm{m}$ for all. Numerals indicate the leaf nubmers according to Scheme 1, apical cell is marked by asterisk; AH: axillary hais of stem leaves; ah: axillary hairs of branch leaves; AHm: axillary hair initials. 82-83, 85, 87-89: longitudinal stem sections; buds in figs $85,87-89$ are at distance of about 50, 200, 250 and $400 \mu \mathrm{m}$ from stem apex correspondingly and shows sequential immersion of branch apical cell into the stem tissie. $\mathbf{8 5}$ and $\mathbf{9 0}$ are a Z-stacks from confocal images, showing (85) apical region, and (90): immersed branch apical cell, note three leaves around it (numbered third to fifth, which is the most probably, as first two merophytes in Isothecium often remain without any lamina, but the variants 1-2-3 and 2-3-4 are also possible, cf. Figs. 1-5); 86: four section of $2 \mu \mathrm{m}$ thick, showing two axillary hairs in axil of young stem leaf (which is shown in 'a'), note their position on two large cells. Scale bars are $20 \mu \mathrm{m}$ for all.

to $92 \mathrm{~g})$. In lower sections this leaf is performed as a single row of cells (not considering occasional irregular divisions, obviously later as having thinner cell walls), thus additionally ensuring that this is a structure derived from one merophyte cell.

The next, fourth and fifth leaves have a clearly delimited structures 2-3 cells wide (marked as $4 \mathrm{a}$ and $5 \mathrm{a}$ in Fig. 91c) at the level of stem surface. They are interpreted as small lobes of compound leaf (cf. e.g. Figs. 3, 8). Note that in both cases these small lobules appear at the anodic leaf corner ("lower" along the leaf spiral), which agrees with the most common case seen in SEM pictures (Fig. 14, 18, 31)
The leaf with the most clear subdivision into halves is the sixth one. It is composed of uniform cells near stem surface (Fig. 92c-g), while the basal layer is clearly separated into two halves (Figs. 92h-1). At the level shown in Fig. $h-j$ the leaf appears as two cell rows, which is a result of cutting through the obliquely transverse [to somewhat periclinal] cell walls (Scheme 2). The clear subdivision of lower row of cells into two convex parts is quite conspicuous here, and their more extensive divisions may cause a tension in directions shown in Scheme 2 by blue arrows. It is resulting in greater extension above these halves, not above median line, as seen at Fig.92h-i-j (cf. Scheme 2, XZ projection). 

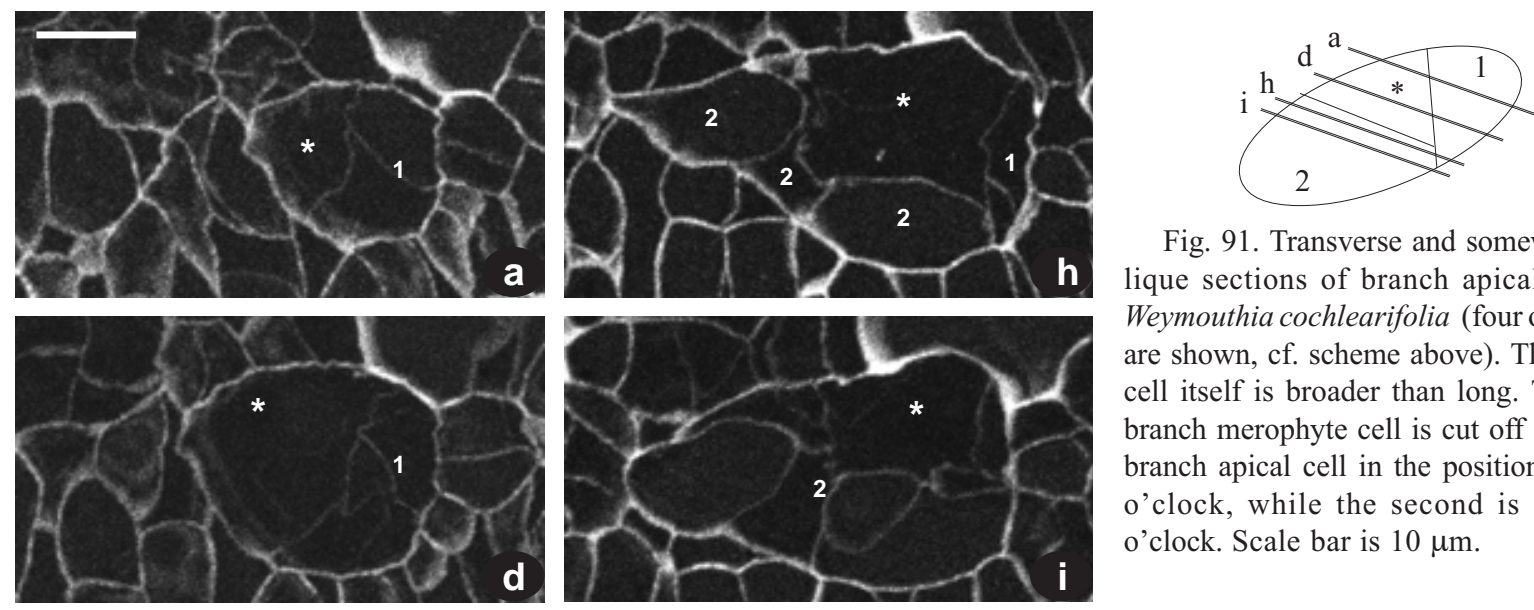

Fig. 91. Transverse and somewhat oblique sections of branch apical cell of Weymouthia cochlearifolia (four out of ten are shown, cf. scheme above). The apical cell itself is broader than long. The first branch merophyte cell is cut off from the branch apical cell in the position of four o'clock, while the second is in eigth o'clock. Scale bar is $10 \mu \mathrm{m}$.

A series of longitudinal sections is shown in Fig. 93. The bud is at $300 \mu \mathrm{m}$ below stem apex, and its stage is in between those shown in Fig. 88 (250 $\mu \mathrm{m}$ below apex) and 89 (ca. $400 \mu \mathrm{m}$ below apex). The whole series includes 26 sections $(=52 \mu \mathrm{m}), 15$ of which are shown (marked by letters a-v, the missing letters mean missing sections, including the last ones, $\mathrm{w}-\mathrm{z}$ ). The apical cell is ovoid, to $33 \mu \mathrm{m}$ along the radial axis, and ca. $20 \mu \mathrm{m}$ in diameter (Fig. 93: 1-m), while the whole bud is $58 \mu \mathrm{m}$ long, $52 \mu \mathrm{m}$ wide and $68 \mu \mathrm{m}$ along the stem radius.

The series demonstrates the lack of lamina in the first and second 'leaves' (i.e., in descendants of the first and second merophytes). The border between the first and second one is "guessed" here, as they are represented by a continuous row of cells and their border is apparent mostly in the transverse section (cf. Fig. 92g).

The third leaf forms a visor above the hollow where the main part of primordium is situated, its lamina is 34 cells long, reaching $20 \mu \mathrm{m}$, which is shorter than axillary hair in its axil. The series comprises two of them, maximally visible in Figs. 93h and 931 (as nearby section has cuts of their margins and thus incomplete). Fig. $93 \mathrm{~m}$ shows one more axillary hair (ah4?), which can be interpreted as axillary hair derived from the leaf \#3 or \#4. The latter interpretation seems more likely as even in stem leaves (Fig. 86) axillary hairs at early stage are developed by two, and the attribution of the 'ah4?' to third leaf requires its assuming as 'ah3c', the third axillary hair in the distance of $12 \mu \mathrm{m}$ (distance from Fig. 93h to $93 n)$.

Marginal parts of leaves 3 and 6 perform separated structures (3a and 6a in Figs. 93q, r, s) that are likely lobules of these leaves, similar to those shown in Fig. $92 \mathrm{c}$ as $5 \mathrm{a}$ and $4 \mathrm{a}$.

The apical cell is at the stage of 12 th merophyte cutting off, it is well hidden and protected by third to seventh leaves and exposed only in four sections (Fig. 93i, not shown to Fig. $96 \mathrm{~m}$ ), thus for $8 \mu \mathrm{m}$ in width, which roughly corresponds to the distance seen in individual sections, where its free part reaches $12 \mu \mathrm{m}$ (Fig. 93k). At the same time, inside the bud, the apical cell is extend- ing since Fig. $93 \mathrm{~h}$ to $93 \mathrm{~s}$, i.e., being at least $20 \mu \mathrm{m}$ wide. Considering its middle part at the level of sections Fig. 931-m, it is clear that its shape is fairly asymmetric, much more protruding to the Fig. 93s side.

The first branch leaves of several cells long are seen in Figs. 87-89 and 93, at about 200, 250, 400, and 300 $\mu \mathrm{m}$ from the stem apex correspondingly. The more developed branch leaves (cf. Figs. 77-81) appear in buds at $600 \mu \mathrm{m}$ from stem apex and below, where in the course of overall stem elongation leaves undergo further development. Sometimes cells have many additional divisions, so the third proximal branch leaf appears to be (5-)1013(-16) cells long (Fig. 77), while at places in the similarly well-developed leaves cells are elongated without divisions, so leaves remain 5 cells long only (Fig. 81).

\section{DISCUSSION}

The structure of branch primordia was found to have a phylogenetic value, as at least twice it appeared to be well coincident with the grouping derived from the molecular phylogenetic analyses, in Brachytheciaceae and Meteoriaceae (Huttunen \& Ignatov, 2004) and basal grade in pleurocarps (Huttunen et al., 2012, 2013; Spirina et al., 2012).

Later the Brachytheciaceae-type of the proximal leaf arrangement around the young bud appeared not to be unique, occurring constantly in Leucodontaceae s. str. (i.e., including Leucodon and Pterogoniadelphus, and excluding Antitrichia and Dozya) and occasionally in Fontinalaceae (Spirina \& Ignatov, 2010, 2011).

According to the present study, the Lembophyllaceae is another group with the Brachytheciaceae-type of the proximal leaf arrangement around its young bud, but unlike Brachytheciaceae, Meteoriaceae and Leucodontaceae, this pattern in the Lembophyllaceae is not stable and varies sometimes within a single shoot.

In this respect the Lembophyllaceae is similar to the Fontinalaceae (Spirina \& Ignatov, 2011), where a fast growth apparently caused the processes of reduction. However in the Fontinalaceae variation in the degree of reduction is rather limited and in most cases the first proximal branch leaf is reduced, while occasionally it is present or otherwise the outermost is the third leaf. 

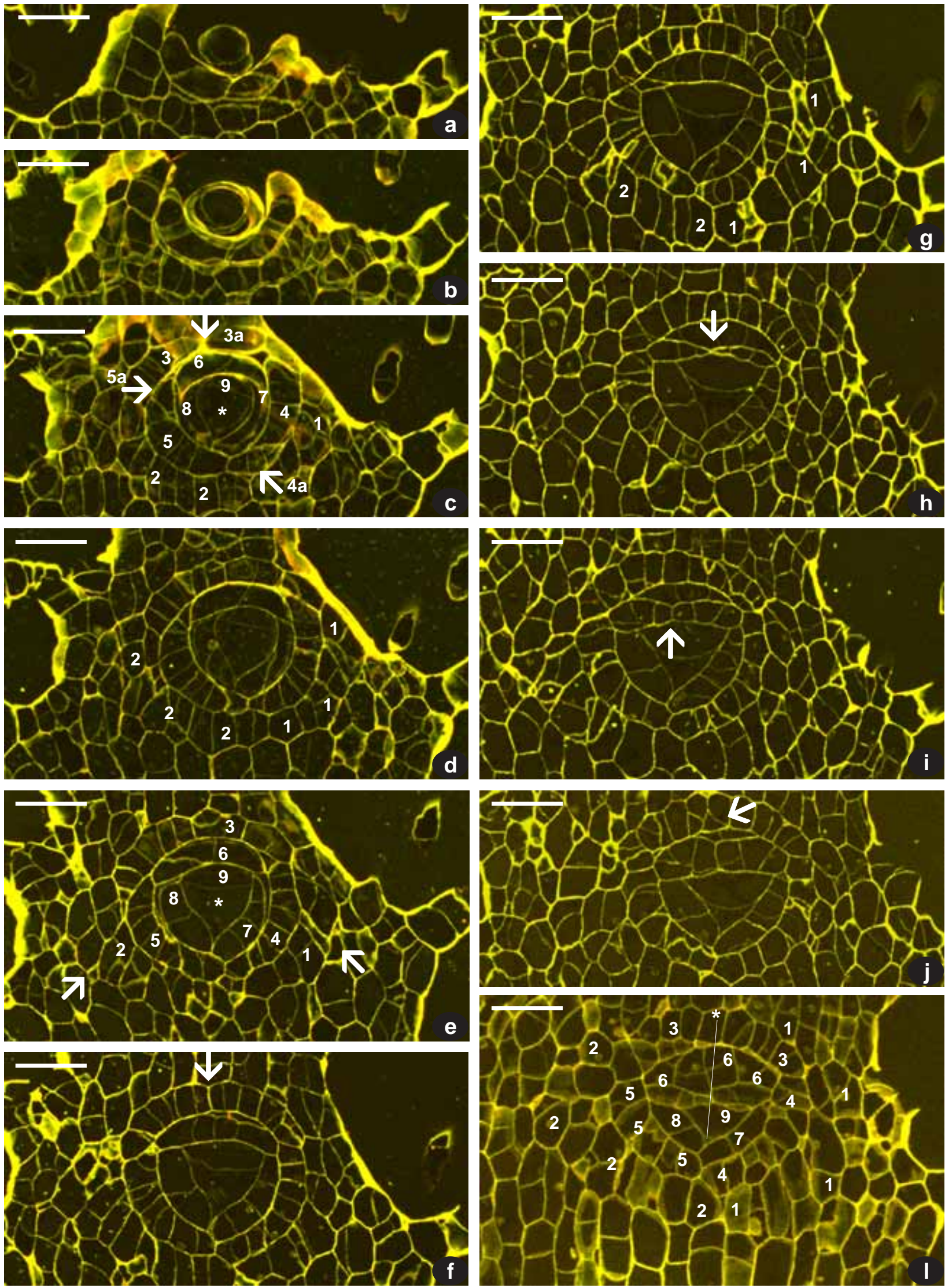

Fig. 92. Longitudinal sections of stem of Weymouthia cochlearifolia showing series of sections transverse to young branch primordium, at ca. $250 \mu \mathrm{m}$ below apex (similar in poristion to bud shown in Fig. 87). The whole series is $22 \mu \mathrm{m}$ (sections are $2 \mu \mathrm{m}$ thick; with one image omitted, between $\mathrm{j}$ and $\mathrm{l}$ ). Numerals mark cells of corresponding leaf/merophyte number according to Scheme 1 , asterisk marks branch apical cell. Arrows point places of leaf splits into lobes. Scale bars are $20 \mu \mathrm{m}$. 

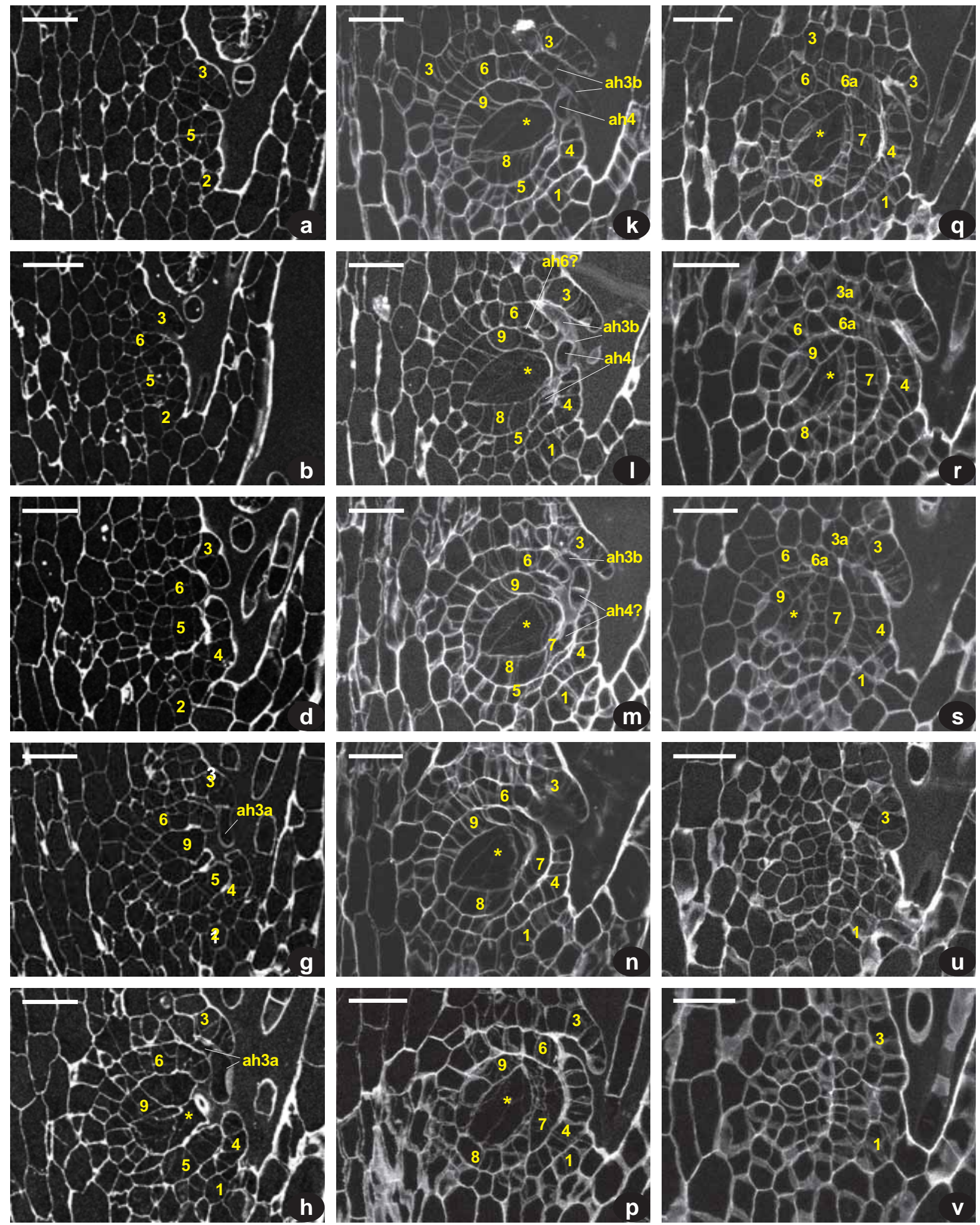

Fig. 93. Longitudinal sections of stem of Weymouthia cochlearifolia showing young branch primordium, at ca. $300 \mu \mathrm{m}$ below apex (in poristion between those shown in Figs. 88 and 89). The whole series includes 26 sections, $2 \mu \mathrm{m}$ thick. Shown are $44 \mu \mathrm{m}$, a-v (missing letters means not shown sections). Numerals mark cells of corresponding leaf/merophyte number according to Scheme 1, asterisk marks branch apical cell. ah\#: axillary hairs with the number of a corresponding branch leaf. Scale bars are $20 \mu \mathrm{m}$. 

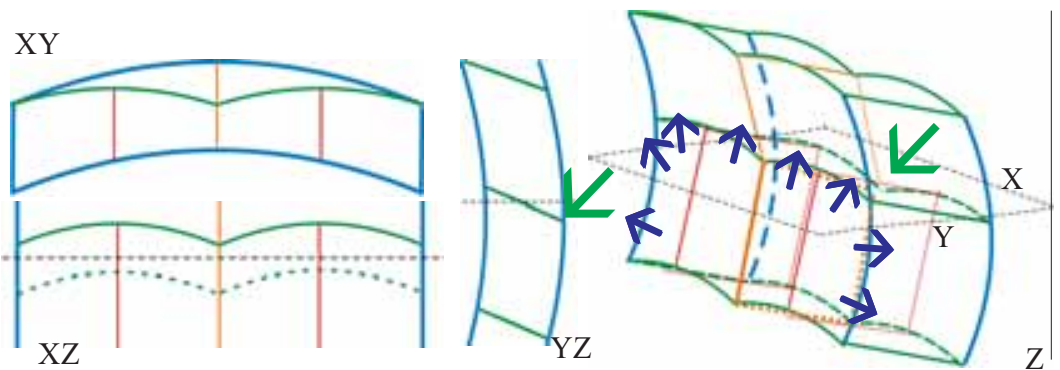

Scheme 2. Explanation on the pattern seen in the sixth leaf in series in Fig. 92: three projections from above and sketch. Cells of the lower row are more extensively dividing, forming convex groups, providing tension marked by blue arrows. Green arrow indicates an external tensions, assuming due to a grove along back median line.
Contrary to this, reduction of proximal branch leaves in the Lembophyllaceae is common, but not specific for a genus, so in many genera one or two leaves appear to be reduced, but at the same time other buds have a complete set of the proximal branch leaves, with the first one being in the 4 o'clock position. Among other possible reasons for this, the variable shape of apical cell and its immediate descendants. In some asymmetric buds first merophytes appear at ca. $120^{\circ}$ (Fig. 91), while in other at less than $90^{\circ}$ (Fig. 85). As discussed for series in Fig. 93, the branch apical cell is asymmetric, while Fig. 92 demonstrates a bud with of perfect tristichous phyllotaxis. The explanation may refer to bud position on stem, which becomes flattened since the first millimeter from the stem apex. Most buds occur laterally, on fairly convex surface, while more rarely primordia occur of more flat upper surface, being likely juvenile sympodial branches (Ignatov \& Hedenäs, 2007) or juvenile perichaetia commonly occurring in such position. The "Brachytheciumtype" of branch primordia is especially common in the core Lembophyllaceae, Camptochaete, Weymouthia and Lembophyllum, where many species are epiphytic plants. However the number of observations does not allow statistical support in this case. The main reason for this is an ambiguous picture seen in the light microscope, and even more clear SEM pictures admit challenge, especially when leaves are sub-opposite and their corners do not overlap each other.

In addition to various reduction, the splitting of proximal branch leaves and development of compound leaves are rather characteristic features of the Lembophyllaceae. Most commonly the proximal branch leaves in pleurocarpous mosses are entire, but their subdivision into lobes is well-documented in e.g. the genus Hypnum s.l., where it has a taxonomic value and received considerable attention of taxonomists (e.g., Ando, 1976). However, numerous published illustrations, as well as our observations ensure that their shape is fairly irregular, likely affected by stem elongation. A somewhat similar case we observed in Fontinalis (Spirina \& Ignatov, 2011). The splitting of proximal leaves in the Leucodontaceae is also fairly irregular, not presented in all species and, if leaves are divided, each leaf looks different from another. The exception in those cases is Hypnum cupressiforme where the foliose structures originated from a single cell appear on the stem without connection one to another, and in this case are fairly regular in their linear shape (Spirina \& Ignatov, 2008).

Another example of more or less regular subdivision of the outer proximal branch leaves into independent foliose structures is known in Thamnobryum (Figs. 64-66). Their identity was understood by Berthier (1971). Similar structures in the Neckeraceae were referred in the recent literature mostly to pseudoparaphyllia (Akiyama, 1990; Akiyama \& Nishimura, 1993; Cubero et al., 2006), a structure whose homology is uncertain. At least in many cases, the apparent phyllotaxis ensures that they are nothing more than strongly splitted parts of the compound leaf (Figs. 61-69). Bud sections in Thamnobryum (Ignatov \& Spirina, 2012) reveals irregular cell arrangement similar to Scheme 1I-J and those shown in Fig. 92c-d for Weymouthia.

Although being very variable, proximal branch leaves of the Lembophyllaceae have one repeatedly appearing feature: the outermost developed leaf and 1-3(-6) next ones are subdivided distally into lobes. These lobes are sometimes unequal and irregular in shape, allowing interpretation of occasional ruptures (Fig. 49). However in some genera, for example in Weymouthia and Camptochaete, bilobed leaves are found in many, although not in all branch primordia. More than half of bilobed leaves was observed in the 12 o'clock position, i.e. in the third leaf. Not rare deep dissections were observed in the fourth and fifth leaves, occasionally in the second, and rarer in the first one. Sixth leaf was found to be bilobed few times, as it is usually hidden below the bigger third one.

Bilobed leaves were found in all studied genera of the Lembophyllaceae and Pterogonium, while in the closely related Neckeraceae and in the genus Ortostichella they were not seem, although a small splitting in the distal part was observed in the latter genus (Figs. 52 leaf \#2, 56 leaf \#2).

This regularity in leaf subdivision in combination with leaf arrangement at a wide angle leads to an interesting feature: leaves are clinching each other at joint in a way of simple slot-lock or carton-box-joints (Figs. 6-7, 70$72,74-76,81)$. The bilobed or laciniate distal edge of proximal branch leaves at this point is essential for such a function. In additions, a similar clasp may form by parts of a single leaf (Fig. 79). A possible adaptive explanation is that the dissecting into lobes or laciniate distal margin allows leaves to form a clasp, proving to branch 
primordium an additional protection (cf. Figs. 70-72, 74). The most outstanding structures were seen in Pilotrichella flexilis (Fig. 74), where an "adventive lobule" exacty fits the slot in between lobes. Similar appendages in Bestia may have a similar functioning. Other examples provide different variants (Figs. 6-7, 35, 40, 70-72, 74-76, 78, 81).

The previous observation on another epiphytic lineage, the family Leucodontaceae (Spirina \& Ignatov, 2010) revealed frequent splitting of the third proximal branch leaf. However, that pattern was found to be fairly irregular, thus it was interpreted as resulting from the rupture caused apparently by tension of the stem elongation. In contrary, in the Lembophyllaceae leaf splitting looks much more regular and is apparently associated with the unequal growth in different layers of leaf. Young leaf base within the bud show definite cell grouping (Fig. 92) apparently correlated with the subsequent leaf splitting, which is most common in leaves with 12 o'clock position (Scheme $1 \mathrm{G}-\mathrm{H}$ ). It seems that more numerous cell divisions in lower cell row, which makes cell groups convex (XZ projections in Scheme 2), may further contribute to more extensive cell elongation above these halves, thus resulting in two lobe development. At the same time, the median line, the oldest cell wall within the corresponding transversal cell row, is surrounded by smaller cells (Figs. 92, 93u: arrow), slowing down the growth of neighboring cells. The cells flanking this median also has the shortest periclinal walls, providing a most probable position of splitting.

Returning to the beginning of paper, the comparison of bilobed leaves in the Lembophyllaceae with Hepaticae can be evaluated only as a superficial analogy. The apical cell of the proximal branch leaf does not produce two initials that may function relatively independently from the outset as in hepatics. There is however an interesting aspect of cell functioning as apical ones along the distal margin of the the proximal branch leaves. Cell arrangement (e.g. in Fig. 75) is similar to that well-known in ordinary moss leaf(Frey, 1970), which means that at least several cells work here as apical ones. And, of course, compound proximal branch leaves of triangular shape grow in a way similar to ordinary leaves. In terms of Kofuji \& Hasebe (2014), they may retain a certain potential of stem cells of one of eigth types recognized in Physcomitrella.

In bilobed leaves, however, 'the apical cells of lobes' are not more active than in other Lembophyllaceae, and the lobes are developed mainly due to cell elongation: their number is often almost the same from base to sinus bottom and to tips of lobes.

The abundant and early developing axillary hairs are a character, which the Lembophyllaceae shares with the Neckeraceae. Contrary to them, species of the Brachytheciaceae, for example, produce rather few axillary hairs (which sometimes are not so easy to find in herbarium specimens). In the young branch of Brachythecium axillary hairs were never seen (Spirina \& Ignatov, 2005) and this seems quite natural, as leaves around branch apical cell tightly surround it, leaving no space for the axillary hairs development between them. In the Lembophyllaceae the branch apical cell is immersed into the stem, so young branch leaves appear on the slope to the hollow and therefore are not so tight to each other, hence leaving a chance for axillary hairs.

The epiphytic lineages in pleurocarpous mosses are known as caused numerous misleading conclusions in taxonomic treatments. During almost whole 20th century, peristome reduction was considered as a basis for classification of Hypnales into two orders, Isobryales, later named Leucodontales and Hypnobryales, later Hypnales (Brotherus, 1925). Molecular phylogenetic data overturned this approach (e.g., Tsubota et al., 2004; Goffinet et al., 2009; Huttunen et al., 2004, 2012), showing that the main distinction of the former are associated with epiphytism. At the same time, a solid ground for the new classification did not appear. Branch primordial characters helped in solution some taxonomic puzzles, but seems they inherit the fate of the "Isobrealean peristome": its correlation with the epiphytic growth appears to be evident.

\section{ACKNOWLEDGEMENTS}

We are grateful to Ye. Kosovich-Anderson fror English correction. The study was partly supported RFBR, 13-04-01592.

\section{LITERATURE CITED}

AKIYAMA, H. 1990. Morphology and taxonomic significance of dormant branch primordia, dormant buds, and vegetative reproductive organs in the Suborders Leucodontineae and Neckerineae (Musci, Isobryales). - Bryologist 93: 395-408.

AKIYAMA, H. \& N. NISHIMURA. 1993. Further studies of branch buds in mosses; "Pseudoparaphyllia" and "Scaly leaves". - J. Plant Res. 106: $101-108$.

ALLEN, B. 1987. On distinguishing Pterobryaceae and Meteoriaceae by means of pseudoparaphyllia. - Bryological Times, 42: 1-3.

ANDO, H. 1976. Studies on the genus Hypnum Hedw. (III). - J. Sci. Hiroshima Univ., Ser. B, Div. 2, Bot. 16: 1-46.

BERTHIER, J. 1971. Recherches sur la structure et le développement de l'apex du gamétophyte feuillé des mousses. - Rev. Bryol. Lichénol. 38: 421-551.

BROTHERUS, V. F. 1906 . Musci . In: Engler, A. \& K. Prantl, eds. Die Natürlichen Pflanzenfamilien, Vol 1 (3). Leipzig : Engelmann, 769-864.

BROTHERUS, V.F. 1925. Musci. - In: A. Engler \& K. Prantl, eds. Die Natürlichen Pflanzenfamilien, 2nd edn. Vol. 11. Leipzig: W. Engelmann. $1-522$

CUBERO, J.I., N. MARCO-SAMANIEGO \& J. ENROTH. 2006. Pseudoparaphyllia in the European and Macaronesian species of Neckera Hedw. (Neckeraceae, Musci). - Cryptogamie, Bryol. 27: 333-342.

FREY, W. 1970. Blattentwicklung bei Laubmoosen. - Nova Hedwigia 20: $463-556$.

FREY, W. \& M. STECH. 2009. Bryophyta (Musci, mosses). - In: Frey, W. [ed.], Syllabus of plant families A. Engler's Syllabus der Pflanzenfamilien. Part 3. Bryophytes and seedless vascular plants. 13th ed.. Gebr. 
Borntraeger Verlagsbuchhandlung, Stuttgart, Germany:116-257.

GOFFINET, B., W.R. BUCK \& A.J. SHAW. 2009. Morphology, anatomy, and classification of the Bryophyta. - In: B. Goffinet \& A.J. Shaw, eds. Bryophyte biology, 2nd edn. Cambridge: Cambridge University Press: 55-138.

HUTTUNEN, S., N. BELL, V.K BOBROVA, V. BUCHBENDER, W.R. BUCK, C.J COX, B. GOFFINET, L. HEDENAS, B.-C. HO, M.S IGNATOV, M. KRUG, O. KUZNETSOVA, I.A MILYUTINA, A. NEWTON, S. OLSSON, L. POKORNY, J.A. SHAW, M. STECH, A. TROITSKY, A. VANDERPOORTEN \& D. QUANDT. 2012. Disentangling knots of rapid evolution: origin and diversification of the moss order Hypnales. - J. Bryol. 34: 187-211.

HUTTUNEN, S. M., M.S. IGNATOV, D. QUANDT \& L. HEDENÄS. 2013. Phylogenetic position and delimitation of the moss family Plagiotheciaceae in the order Hypnales. - Bot. J. Linn. Soc. 171(2): 330353 .

HUTTUNEN, S. \& M.S. IGNATOV. 2004. Phylogeny of the Brachytheciaceae (Bryophyta) based on morphology and sequence level data.Cladistics 20: 151-183.

HUTTUNEN, S., M. IGNATOV, K. MÜLLER \& D. QUANDT. 2004. The phylogeny and evolution of epiphytism in three moss families Meteoriaceae, Brachytheciaceae and Lembophyllaceae. - Monogr. Syst. Bot. Missouri Bot. Gard. 98: 328-361.

IGNATOV, M.S. 1999. On pseudoparaphyllia in Brachytheciaceae and Meteoriaceae (Musci). - Acta Botanica Fennica 165: 73-84.

IGNATOV, M.S., A.A. GARDINER, V.K. BOBROVA, I.A. MILYUTINA, S. HUTTUNEN \& A.V. TROITSKY. 2007. On the relationships of mosses of the order Hypnales, with special reference to taxa traditionally classified in the Leskeaceae. -In: A.E. Newton \& R.S. Tangney (eds.), Pleurocarpous mosses: systematics and evolution. Syst. Assoc. Special Vol. 71: 177-213.

IGNATOV, M.S. \& U.N. SPIRINA. 2012. Morphogenesis of proximal branch leaves in mosses. - Russ. J. Developm. Biol. 43 (3): 148-156.

IRELAND, R.R. 1971. Moss pseudoparaphyllia. - Bryologist 74: 312330 .
KOFUJI, R. \& M. HASEBE 2014. Eight types of stem cells in the life cycle of the moss Physcomitrella patens. - Current Opinion in Plant Biology 17: 13-21.

QUANDT, D., S. HUTTUNEN, R. TANGNEY \& M. STECH. 2009. Back to the Future? Molecules Take Us Back to the 1925 Classification of the Lembophyllaceae (Bryopsida). - Systematic Botany 34(3): 443-454.

SCHUSTER, R.M. 1966. Hepaticae and Anthocerotae of North America. Vol. 1. - Columbia University Press, New York, 802 pp.

SPIRINA, U.N. \& M.S. IGNATOV. 2005. Comparison of early stages of branch development in Brachythecium and Calliergon (Bryophyta).Arctoa 14: 211-222.

SPIRINA, U.N. \& M.S. IGNATOV. 2008. Branch development and pseudoparaphyllia of Hypnum cupressiforme (Hypnales, Musci). - Arctoa 17: 139-160.

SPIRINA, U.N. \& M.S. IGNATOV. 2010. On the branch development in Leucodon (Leucodontaceae, Bryophyta). - Arctoa 19: 139-150.

SPIRINA, U.N. \& M.S. IGNATOV. 2011. On the branch development in Fontinalaceae (Bryophyta). - Arctoa 20: 119-136.

SPIRINA, U.N., M. SHIMAMURA \& M.S. IGNATOV. 2012. On the branch primordial of basal pleurocarpous mosses. - Arctoa 21: 221236.

TANGNEY, R.S. 1997. A generic revision of the Lembophyllaceae. $-J$. Hattori Bot. Lab. 81: 123-153.

TROITSKY, A.V., M.S. IGNATOV, V.K. BOBROVA \& I.A. MILYUTINA. 2008. Contribution of genosystematics to current concepts of phylogeny and classification of Bryophytes. - Biochemistry (Moscow) 72(12): 1368-1376.

TSUBOTA, H., E. DE LUNA, D. GONZÁLEZ, M.S. IGNATOV \& H. DEGUCHI. 2004. Molecular phylogenetics and ordinal relationships based on analyses of a large-scale data set of $600 \mathrm{rbcL}$ sequences of mosses. - Hikobia 14: 149-170.

WARNSTORF, C. 1906. Kryptogamenflora der Mark Brandenburg und Angrenzender Gebiete. Laubmoose, 2 Bd. - Leipzig, Verlag von Gebrüder Borntraeger, 1666 pp. 